Article available at nttp://Www.parasite-journal.org or nttp://dx.dol.org/10.1051/parasite/1996032131

\title{
High prevalence of Ancylostoma SPP. infection in dogs, ASSOCIATED WITH ENDEMIC FOCUS OF HUMAN CUTANEOUS LARVA MIGRANS, IN TACUAREMBO, URUGUAY
}

\author{
MALGOR R.", OKU Y.**, GALLARDO R." \& YARZÁBAL L."*
}

\section{Summary :}

A helminthological survey of the intestinal parasites in stray dogs was conducted in urban and suburban area of Tacuarembó, Uruguay, during winter time. Eighty stray dogs captured in the city were necropsied. Seventy nine dogs $(98.8 \%)$ were positive for helminth infection. Seventy seven (96.3\%) were parasitized by hookworms. Two species of hookworms were found: Ancylostoma caninum $96.3 \%$ and A. braziliense $49.4 \%$. This is the first report of the prevalence of $A$. braziliense in Uruguay. Considering that incidences of human cutaneous larva migrans caused by the migration of hookworms larvae were restricted mainly to the northen part of Uruguay and that only A. caninum were reported to be prevalent in the southen part, it is supposed that $A$. braziliense is the primary causative agent of human cutaneous larva migrans in Uruguay.

KEY WORDS : helminth, nematoda, dog, Ancylostoma, prevalence, cutaneous larva migrans, Uruguay.
Résumé : ForTe PRÉVALENCE DE L'INFECTION CANINE À ANCYLOSTOMA SPP. ASSOCIÉE À UN FOYER ENDÉMIQUE HUMAIN DE LARVA MIGRANS CUTANÉE À TACUAREMBO, URUGUAY

Une étude helminthologique concernant les parasites intestinaux chez des chiens vagabonds a été réalisée pendant l'hiver, dans les quartiers urbains et suburbains de la ville de Tacuarembó en Uruguay. Parmi les chiens capturés, quatre-vingts ont été autopsiés. Soixante dix-neuf chiens $(98,8 \%)$ ont présenté une infection par helminthes. Soixante dix-sept $(96,3 \%)$ étaient parasités par des ankylostomes. Deux espèces de ce genre ont été trouvées: Ancylostoma caninum 96,3\% et A. braziliense 49,4\%. Ce travail constitue le premier rapport de prévalence de A. braziliense en Uruguay. En considérant que l'incidence humaine de larva migrans cutanée, causée par la migration de larves d'ancylostomatidés, se limite surtout à la région nord du pays, et que seulement $\mathrm{A}$. caninum a été rapporté dans la région sud du pays, nous supposons que A. braziliense est le principal agent étiologique de la larva migrans cutanée en Uruguay.

MOTS CLÉS : helminthe, nématode, chien, Ancylostoma, prévalence, larva migrans cutanée, Uruguay.

\section{INTRODUCTION}

1 he zoonosis caused by canine parasites are an interesting subject to study because of the close relationship between humans and dogs (Elliot et al., 1985).

Uruguay is an endemic country of hydatidosis/echinococcosis, one of the most important zoonosis, caused by Echinococcus granulosus, and the disease is usually related with rural areas, where the cycle of the parasite is easily maintained (Purriel et al., 1973). Numerous work has been carried out on hydatidosis in Uruguay, however, other important zoonosis caused by canine parasites were not studied adequately.

The disease called " creeping eruption ", "cutaneous larva migrans " or "sandworm " is caused by the infective larvae (L3) of hookworms wich penetrate the

\footnotetext{
* Unidad de Biología Parasitaria, Instituto de Higiene, Universidad de la República Oriental del Uruguay, Avda. Alfredo Navarro 3051, CP 11600, Montevideo, Uruguay. Fax : 598-2-473074.

** Department of Animal Disease Control, Graduate School of Veterinary Medicine, Hokkaido University, Sapporo 060 Japan. Fax : 011709-1593.

Correspondence : Ramiro Malgor.
}

unbroken skin of man and migrate through subcutaneous tissue. As humans are not adequate hosts they are unable to complete their migratory cycle and produce skin lesions. The principal hookworms causing cutaneous larva migrans are Ancylostoma braziliense, Uncinaria stenocephala, and Bunostomum phlebotomum, while Ancylostoma caninum plays only a minor role (Soulsby, 1987). These agents are cosmopolitan in temperate and tropical areas. Human infection usually occurs in areas where recreational exposure to contaminated soil takes place, such as sandy beaches or parks.

Ferreira and Ferreira (1991) reported 89 human cases of cutaneous larva migrans in Tacuarembó from 1968 to 1989. All patients were residents of urban and suburban areas and the incidence was highest in summer and beginning of autumn. Ninety percent of cases were in the age group of 1 to 10 years old.

In Montevideo, because of the high number of stray dogs and the behavior of dog owners that allow their animals to defecate anywhere and leaves their feces behind, contamination with hookworm eggs was recognized in many parks and public places (Perez, 1991). 
However, the incidence of cutaneous larva migrans is very low.

This study was conducted to investigate the prevalence of gastro-intestinal helminths of dogs with special emphasis on the prevalence of $A$. braziliense as the causative agent of human cutaneous larva migrans.

\section{MATERIALS AND METHODS}

1 he survey was carried out in Tacuarembó, a small city located in the north of Uruguay at $31^{\circ} 42^{\prime} 7$ South latitude and 55 $59^{\prime} 5$ West longitude and at 134.03 meters above sea level. It has 40,000 inhabitants, with an average annual rain precipitate of 1,100-1,200 mm, and an average annual temperature of $17-18{ }^{\circ} \mathrm{C}$. The average temperature in summer during the last four years was $22.5^{\circ} \mathrm{C}$ (range $6{ }^{\circ} \mathrm{C}$ to $38.5^{\circ} \mathrm{C}$ ) and in winter was $12{ }^{\circ} \mathrm{C}$ (range $-6{ }^{\circ} \mathrm{C}$ to $30^{\circ} \mathrm{C}$ ). The rain precipitation in summer in the last 5 years was 400 to $500 \mathrm{~mm}$ annually.

From June to September 1992, 80 stray dogs (51 male and 28 female) captured for the Control Program on Hydatid Disease in Tacuarembó were necropsied. The animals came from urban and sub-urban areas of the city. The small intestine of each dog was removed and divided into 3 equal parts in length, slit longitudinally and the mucosae scraped. To avoid biohazardous risks, the contents were heated in a boiling waterbath. The material was rinsed with tap water through a sieve mesh (aperture $150 \mu$ ) and the retained on the mesh was collected and sedimented.

The parasites were collected from the sedimentation and fixed in $10 \%$ formalin. All the hookworms were transparenced with lactophenol and identified under microscope, by the characteristics of their buccal capsules (Matsusaki et al., 1965; Yoshida, 1971; Yoshida et al., 1974).

\section{RESULTS}

he prevalence of helminth infections is shown in Table I. Seventy nine of the dogs (98.8\%) - were positive for helminth infections. Seventy seven of the dogs $(96.3 \%)$ harboured hookworms. Two species were identified: Ancylostoma caninum and $A$. braziliense. All infected dogs harboured A. caninum while $49.4 \%$ of them harboured $A$. braziliense. The most common species coinfected were Ancylostoma caninum-A. braziliense, followed by A. caninum-Dipyllidium caninum.

Figures 1 and 2 show the frequency distributions of worm burden in each species of Ancylostoma.

\begin{tabular}{lcc}
\hline \multicolumn{1}{c}{ Parasite } & No of dogs & $\%$ \\
\hline Echinococcus granulosus & 3 & 3.8 \\
Taenia sp. & 6 & 7.5 \\
Multiceps sp. & 1 & 1.3 \\
Dipylidium caninum & 30 & 37.5 \\
Toxocara canis & 8 & 10.0 \\
Ancylostoma caninum & 77 & 96.3 \\
Ancylostoma braziliense & 38 & 49.4 \\
\hline
\end{tabular}

Table I. - Prevalence of parasites in dogs in Tacuarembó-Uruguay

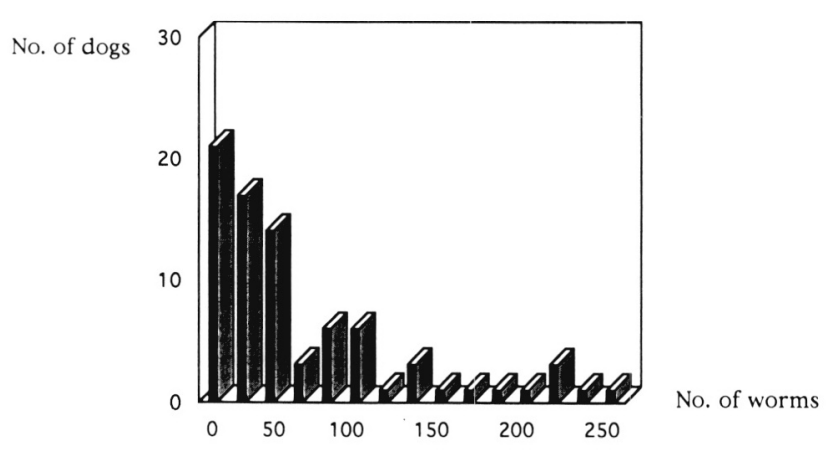

Fig. 1. - Frequency distribution of A. caninum.

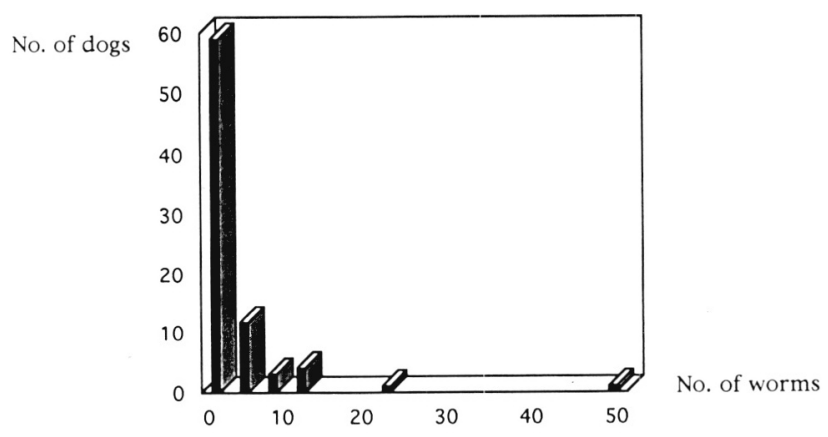

Fig. 2. - Frequency distribution of A braziliense.

The mean intensity of infection was 57.5 (range 1-246) for A. caninum and 6.7 (range 1-57) for A. braziliense. No correlation was found between sex of host and worm burden.

The distribution of worm burden in $A$. caninum was found to be hyper-dispersed; only $6.5 \%$ of the dogs had more than 200 parasites and the majority had less than 100 with $45.5 \%$ of the dogs harboring between 10 and 50 parasites.

The male/female ratio of parasite recovered was $0.6 / 1$ and $0.5 / 1$ for $A$. caninum and A. braziliense, respectively.

The distribution in the small intestine for $A$. caninum was: $44 \%$ in the anterior, $45 \%$ in the middle and $11 \%$ 
in the posterior part; whereas A. braziliense was: $69 \%$, $25 \%$ and $6 \%$, respectively. The preference for the anterior intestine is more evident in A. braziliense.

\section{DISCUSSION}

I $\mathrm{n}$ this study, 7 species of helminths were found in dogs in Tacuarembó. Even though the dogs were captured in urban and suburban area, small number of dogs were infected with $E$. granulosus. This finding presents an important implication in epidemiology of the disease that the hydatidosis is not only a rural problem. The source of E. granulosus found in the dogs was not clear, however, it may be related to the existance of small illegal slaughterhouses around the city.

More significantly, high prevalence of Ancylostoma spp. was revealed in stray dogs in Tacuarembó in this study.

Table II shows the prevalence of Ancylostoma sp. in dogs, reported in different countries. Although methods with different sensitivity were used, the prevalence of Ancylostoma sp. found in Tacuarembó, Uruguay, was ranked as the highest, suggesting that the environment of Tacuarembó is suitable for the transmission of $A n c y$ lostoma sp.

The survey was carried out in winter when the mean temperature in Tacuarembó is $12^{\circ} \mathrm{C}$ and sometimes reaches under $0{ }^{\circ} \mathrm{C}$. Because the development of eggs to larva (L3) is restricted at cold temperature (Soulsby, 1987), the transmission of hookworms is supposed to be low in winter.

It was reported that the prevalence rates varied with the season and increased in the warm seasons (Mitra et al., 1990). Therefore, it is indicated that the transmission of hookworms is higher in summer in Tacuarembó and the rate of infection or worm burden is also higher. Supporting this, all human cases of cutaneous larva migrans reported in Tacuarembó by Ferreira and Ferreira (1991) were found in summer and at the begining of autumm, when the skin is more exposed and the number of infective larvae in the environment is higher. Cutaneous larva migrans were also found in Salto, located in the north part of Uruguay, and Drs. Suarez and Calegari found 17 cases in summer from December 1982 to May 1983 (personal communication).

In the south of the country, however, cutaneous larva migrans are not common. A study carried out in Montevideo, the capital of Uruguay and located in the south of the country, showed that the prevalence of hookworm of 60 stray dogs examined was high (38\%) but A. caninum was the only species found (Dr. P. Cabrera, 1987). A braziliense which causes human cutaneous larva migrans has not been found in Monte- video. Most human cases reported in Montevideo, ocurred in patients infected during holiday time in Brazil.

Because $A$. braziliense needs higher temperature to successfully develop and complete its cycle, compared to $A$. caninum, it is supposed that $A$. braziliense can not maintain its life cycle in colder south region of Uruguay such as Montevideo. Considering that cutaneous larva migrans were found only in the north region where $A$. braziliense was prevalent, it is supposed that the causative agent of cutaneous larva migrans in Uruguay is mainly $A$. braziliense.

Further studies are necessary to know what ecological factors make Tacuarembó and probably other cities in the north of the country a good environment for the transmission of $A$. braziliense. It is also necessary to study the prevalence of $A$. braziliense in cats, another suceptible host for this parasite for understanding the role of cat in this zoonosis.

High prevalence of $A$. braziliense shown by this study points out the importance of this parasite in Uruguay as the cause of human illness. Although the prevalence of A. caninum was very high, human cases of eosinophilic enteritis has not been reported in Uruguay. As Olivera et al. (1990) reported that improvement of sanitary conditions and education of dog owners have reduced the prevalence of Ancylostoma sp. in dogs in Brazil, it is necessary in Uruguay to introduce some regulations for regular treatment of pets and to change the behaviour of people to prevent potentially more severe outbreak of the zoonosis.

\begin{tabular}{|c|c|c|c|c|c|}
\hline \multirow[b]{2}{*}{$\begin{array}{l}\text { Athens } \\
\text { (Georgia) }\end{array}$} & \multirow{2}{*}{$\begin{array}{c}\text { Prevalence \% } \\
86.0 \text { A.c. }\end{array}$} & \multirow{2}{*}{$\begin{array}{l}\text { Year } \\
1951\end{array}$} & \multirow{2}{*}{$\begin{array}{c}\begin{array}{c}\text { Mean } \\
\text { intensity }\end{array} \\
141\end{array}$} & \multicolumn{2}{|c|}{ Method } \\
\hline & & & & $\mathrm{N}$ & (5) \\
\hline Japan (Shiga) & 18.6 A.sp & 1984 & & $\mathrm{~N}$ & (16) \\
\hline Spain (Galicia) & 24.6 A.sp & 1987 & & E & (2) \\
\hline Jamaica & 22.7 A.sp & 1986 & & $\mathrm{E}$ & (14) \\
\hline $\begin{array}{l}\text { Australia } \\
\text { (Queensland) }\end{array}$ & 20.1 A.sp & 1987 & & $\mathrm{E}$ & (4) \\
\hline $\begin{array}{l}\text { Nigeria } \\
\text { (Calabar) }\end{array}$ & 26.8 A.sp & 1984 & & $\mathrm{E}$ & (17) \\
\hline India & 26.6 A.sp & 1988 & & $\mathrm{E}$ & (10) \\
\hline $\begin{array}{l}\text { Brazil } \\
\text { (Sao Paulo) }\end{array}$ & 59.8 A.sp & $1980-85$ & & $\mathrm{E}$ & (1) \\
\hline $\begin{array}{l}\text { Brazil } \\
\text { (Minas Gerais) }\end{array}$ & 61.2 A.sp & $1981-86$ & & $\mathrm{E}$ & (11) \\
\hline $\begin{array}{l}\text { Uruguay } \\
\text { (Montevideo) }\end{array}$ & 38.0 A.c. & 1987 & & $\mathrm{~N}$ & (3) \\
\hline $\begin{array}{l}\text { Uruguay } \\
\text { (Tacuarembó) }\end{array}$ & $\begin{array}{l}96.3 \text { A.c. } \\
49.4 \text { A.b. }\end{array}$ & 1992 & $\begin{array}{l}57.5 \\
6.7\end{array}$ & $\mathrm{~N}$ & \\
\hline
\end{tabular}

A.c. A. caninum; A.b. A. braziliense; A. s.p. Ancylostoma sp.; $\mathrm{N}$ : necropsy; E: egg examination.

Table II. - Prevalence of Ancylostomiasis in dogs in different countries. 


\section{ACKNOWLEDGEMENTS}

$\checkmark$ his work was suported by JICA, Japan International Cooperatioon Agency and Ministry of Education Science and Culture, Japan (grant $n^{\circ}$ 06041005).

We are grateful for the collaboration of the Municipal Government of Tacuarembó.

\section{REFERENCES}

ANgelis C.V.D. et al. Infections by Ancylostoma and Toxocara in dogs and cats caught on the streets of Sao Paulo City, Brazil. Revista de Saude Publica, 1988, 22, 341-343.

ARes M.M., Sela P.M. \& Arias F.M. Epidemiology of intestinal parasite of dogs in Galicia. Revista Iberica de Parasitologia, 1987, 47, 335-339.

Cabrera P.A., Sampaio I., Parietti S., lavarello L., Correa O., Bossi M. \& Rossi D. Relevamiento de parásitos con significación zoonotica en Canis familiaris. IV Congreso Nacional de Veterinaria. Montevideo-Uruguay 1987.

Cornack K.M. \& O'Rourke P.K. Parasites of sheep dogs in the Charliville district, Queensland. Australian Veterinary Journal, 1991, 68.

COOPERRIDER D.E. Recent information on hookworms of the dog. Veterinary Medicine, 1953, 48, 6.

Elliot D.L., Tolle S.W., Goldberg L. \& Miller J.B. Pet-associated illness. The New England Joumal of Medicine, 1985, 16, 985-992.

Ferreira B.A. \& Ferreira M.A. Larva Migrans Cutanea: Presentación de 89 casos registrados en el departamento de Tacuarembó. X Congreso Latinoamericano de Parasitología Montevideo-Uruguay 1991

KRUPP I.M. Effects of crowding and superinfection on habitat selection and egg production in Ancylostoma caninum. The Journal of Parasitology, 1961, 47, 957-961.

Matsusaki G., Takekawa T. \& Mogi K. Studies on the Life History of the Hookworms. Part X The Morphological Studies on the Development of the Adult of A. caninum in the Normal Host. Yokohama Medical Bulletin, 1965, 16, 65-94.

Mitra K., Ghosh A., Ghosh L., Mitra S., Chaudhuri S. \& BISWAS G. Ancylostomiasis in pet dog - a note. Indian Veterinary Medical Journal, 1990, 14, 215-217.

Oliveira P.R., Silva P.L., Parreira V.F., Ribeiro S.C.A. \& Gomes J.B. Prevalence of endoparasites in dogs in the region of Uberlandia, Minas Gerais State. Brazilian Joumal of Veterinary Research and Animal Science, 1990, 27, 193-197.

Perez G., Lllanes B., Winkowsky K., Saldana J. \& Holcman B. Contaminación de plazas y parques públicos por helmintos en Montevideo. X Congreso Latinoamericano de Parasitología Montevideo-Uruguay 1991.

Purriel P., Schantz P.M., Beovide H. \& Mendoza G. Human Echinococcosis (hydatidosis) in Uruguay a comparison of morbidity and mortality. Bulletin of the Wold Health Organization, 1973, 49, 395-402.

RoBinson R.D., Thompson D.L. \& Lindo J.F. A survey of intestinal helminths of well-cared-for dogs in Jamaica, and their potential public health significance. Journal of Helminthology, 1989, 63, 32-38.

SoulsBy E.J.L. Helminths, Arthropods and Protozoa of Domesticated Animals. 7th Ed. 1987.

Tada Y., Ohta T., Soohara S. \& Suzuki Y. Helminth infections of dogs in Shiga, Japan with reference to occult infection of Dirofilaria immitis. Journal of Veterinary Medical Science, 1991, 53, 359-360.

Ugochukwu E.I. \& EJIMAdu K.N. Studies on the prevalence of gastrointestinal helminths of dogs in Calabar, Nigeria. International Journal of Zoonoses, 1985, 12, 214-218.

Yoshida Y. Comparative studies on Ancylostoma braziliense and Ancylostoma ceylanicum. I. The adult stage. The Journal of Parasitology, 1971, 57, 983-989.

Yoshida Y., Kondo K., Kurimoto H., Fukutome S. \& ShiraSAKA S. Comparative studies on Ancylostoma braziliense and Ancylostoma ceylanicum. III. Life history in the definitive host. The Journal of Parasitology, 1974, 60, 636-641.

Reçu le 22 novembre 1995 Accepté le 5 mars 1996 